\title{
Design and Assessment of Marketing Professional Practice Teaching System Based on Integration of Industry and Education*
}

\author{
Xinling Wu \\ Guangdong University of Foreign Studies South China Business College \\ Guangzhou, China 510545
}

\begin{abstract}
The background of production and education integration and collaborative education has been proposed to support colleges and universities to closely focus on industrial needs, strengthen practical teaching, and improve the training system based on applied talents. On the basis of cultivating marketing professionals, the article explores the characteristics of business cognition and business education, integrates into the background of integration of production and education, and school-enterprise cooperation, and establishes a threedimensional, multi-level and open-ended practical teaching system with "class, training, competition, creation" four integration and "point-line-face-body" four-dimensional combination. It also proposes to focus on process assessment, student-centered, introduction of companies or third-party evaluations.
\end{abstract}

Keywords-integration of production and education; practical teaching system; assessment and evaluation; marketing professionals

\section{INTRODUCTION}

The "National Standards for Undergraduate Professional Teaching Quality in General Institutes of Higher Education" issued at the beginning of 2018 has clear requirements for the design of practical teaching systems for undergraduate majors such as marketing. In the curriculum system, theoretical teaching and practical teaching are clearly included; the practical teaching curriculum system includes practical training courses, internships, social practice and graduation thesis; it is clear that the total credits are 140-160 credits, and the proportion of practical teaching credits is not lower than $15 \%$ of the total credits. In the teaching facilities requirements, teaching funding requirements, quality assurance system design, there are minimum requirements for the practical teaching part.

Strengthening the practice teaching link is the cornerstone for cultivating applied talents. By effectively designing the marketing professional practice teaching

*Project: This paper is the phrased result of the school education cooperation and education project of the Guangdong Provincial Education Department (No. PROJ1001957355224698880), the school-level teaching achievement award cultivation project (2018JXCG04), the school-level quality engineering construction project (2017JD01, 2016JXTD01), and school-level marketing key professional construction. system and carrying out rich and applicable practical teaching activities, it can not only gradually cultivate the practical spirit and practical awareness of marketing students, but also gradually improve students' practical ability and problem-solving ability. In professional practice activities, it can make students consolidate theoretical knowledge, broaden their horizons, enhance their analytical and exploratory skills, and improve their teamwork and brainstorming skills.

\section{CONSTRUCting A MARKETING PROFESSIONAL}

PRACTICE TEACHING SYSTEM BASED ON THE BACKGROUND OF INTEGRATION OF PRODUCTION AND EDUCATION

\section{A. Educational Background of Integration of Production and Education and Collaborative Education}

Deepening the integration of production and education, and promoting the organic connection between the education chain, the talent chain, the industrial chain and the innovation chain is an urgent requirement for promoting the structural reform of the supply side of human resources. Under the new situation, it will be necessary to comprehensively improve the quality of education, expand employment and entrepreneurship, and promote economic transformation. It is of great significance to upgrade and cultivate new kinetic energy for economic development. Since the 19th National Congress, the strategic deployment of talents to rejuvenate the country proposed by General Secretary Xi Jinping has been a heated discussion and active deployment for the "acceleration of the education modernization and making the education of the people's satisfaction." Since the end of 2017, the State Council and the education departments have issued a number of documents on deepening the "integration of production and education", promoting "school-enterprise cooperation" and "collaborative education". The document pointed out that it will strongly support colleges and universities to closely focus on industrial needs, strengthen practical teaching, and improve the training system based on applied talents.

Against this background, colleges and universities need to change the concept of education, and combine the teaching activities with the requirements of enterprises for talent quality. The survival and development of colleges and 
universities urgently require long-term and effective cooperative relations with enterprises. They need to jointly explore all-round, multi-modal and deep-level schoolenterprise cooperation methods to jointly cultivate applied, practical, and compound college students with strong adaptability, strong hands-on ability, and professional knowledge. The reform of marketing professional education is even more imperative.

\section{B. Design of Marketing Professional Practice Teaching System Against the Background of Integration of Production and Education}

The practical teaching system refers to the specific teaching content presented by each practical teaching link through reasonable structural configuration and regular scientific layout. Specifically, the practical teaching links of the marketing profession are based on the ability training as the aim, and the professional application ability as the main body. According to the basic theoretical knowledge, professional knowledge, professional skills, business operations and comprehensive application and other practical application capabilities, practical teaching content are arranged step by step with reasonable allocation, scientific matching, and mutual complementation, specifically implementing the practical teaching objectives and teaching tasks in various practical teaching links.

On the basis of following the characteristics of teaching cognition and business education, the training of marketing professionals is integrated into the background of integration of production and education, school-enterprise cooperation, and establishes a three-dimensional, multi-level and open practical teaching system. Through the combination of extracurricular and extracurricular integration, coordination between the school and the school, the combination of theoretical teaching and practical teaching, the combination of employment and entrepreneurship, the integration of science and education, the integration of production and education, and so on, it can provide students with a diversified and all-round "knowledge — ability — quality" three-way practice, the four integration of "class, training, competition, creation", and four-dimensional practice teaching environment of "point-line-face-body".
1) "Point-line-face-body" four-dimensional marketing practice teaching system: The marketing practice teaching link is an important comprehensive teaching method that is carried out along with classroom teaching, simulation teaching and case teaching, and assists students in integrating their knowledge and hands-on practice. In this way it will enable students to get rid of the constraints of closed doors and papers, so that each student is in a real and specific environment, immersively participate in corporate case data collection and practical work to cultivate their hands-on ability, comprehensive analysis of problems, problem-solving ability. Through research, the research group proposed to construct a "point to line and then plane and overall" practical teaching system, which is based on the marketing professional training program, taking the practice in the class as the teaching "point", through professional practice, independent practical classes, etc., linking the course points into "line", using the on-campus training platform, graduation thesis, entrepreneurial competition, etc., to form a "face", and finally form a professional "body" in the form of graduation internship and employment, and achieve aims of comprehensive improvement of the practical ability of marketing students.. The "point" is the theoretical knowledge point and practice/experimental link of a certain course of marketing major, and the "line" is the connection between different courses (or course practice links) of the major. "Face" is the knowledge/actual content and connection involved in the profession. "Body" forms a complete knowledge system and a high comprehensive professional technical ability in the professional field. The system pays attention to the system design, supports and guarantees the professional practice teaching through the organic combination of extracurricular and extracurricular integration, coordination between the school and the school, taking into account the theoretical teaching and practical teaching, giving full play to the role of the training base inside and outside the school, and fully applying the industrial resources. (See "Table I")

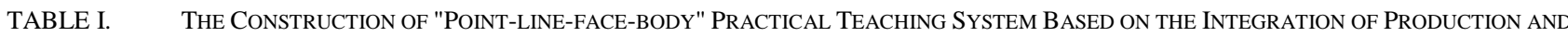
EDUCATION

\begin{tabular}{|c|c|c|c|c|c|c|}
\hline Stage & Level & Time & Location & Practical content & $\begin{array}{c}\text { Cultivating ability } \\
\text { and quality }\end{array}$ & Practice mode \\
\hline "point" & Low & $\begin{array}{l}\text { In-class } \\
\text { arrangement }\end{array}$ & $\begin{array}{l}\text { In-school or } \\
\text { enterprise } \\
\text { into the } \\
\text { classroom }\end{array}$ & $\begin{array}{l}\text { Strengthen students' } \\
\text { cognition, understanding } \\
\text { and application of } \\
\text { theoretical knowledge } \\
\text { points through practical } \\
\text { teaching links in the } \\
\text { classroom }\end{array}$ & $\begin{array}{l}\text { Basic theory } \\
\text { Professional } \\
\text { knowledge }\end{array}$ & $\begin{array}{l}\text { Enterprise case studies, } \\
\text { scenario simulations, group } \\
\text { discussions, personal } \\
\text { presentations, etc. }\end{array}$ \\
\hline "line" & $\begin{array}{l}\text { Less } \\
\text { lower }\end{array}$ & Sophomore & $\begin{array}{l}\text { In-school or } \\
\text { enterprise } \\
\text { into the } \\
\text { classroom }\end{array}$ & $\begin{array}{l}\text { Combine the curriculum } \\
\text { knowledge points into a line } \\
\text { to strengthen the basic skills }\end{array}$ & $\begin{array}{l}\text { Basic skills } \\
\text { Business operation }\end{array}$ & $\begin{array}{l}\text { Software operation course, } \\
\text { course sub-training, course } \\
\text { papers, analogue simulation, } \\
\text { on-site teaching }\end{array}$ \\
\hline
\end{tabular}




\begin{tabular}{|c|c|c|c|c|c|c|}
\hline Stage & Level & Time & Location & Practical content & $\begin{array}{c}\text { Cultivating ability } \\
\text { and quality }\end{array}$ & Practice mode \\
\hline "face" & $\begin{array}{l}\text { Less } \\
\text { higher }\end{array}$ & $\begin{array}{l}\text { Junior, first } \\
\text { term of } \\
\text { senior year }\end{array}$ & $\begin{array}{l}\text { On-campus } \\
+\quad \text { off- } \\
\text { campus } \\
\text { (industry or } \\
\text { enterprise) }\end{array}$ & $\begin{array}{l}\text { Use training platforms, } \\
\text { practice bases, or actual } \\
\text { combat projects, thesis } \\
\text { design, etc. to conduct } \\
\text { comprehensive training to } \\
\text { form a comprehensive } \\
\text { quality }\end{array}$ & $\begin{array}{l}\text { Logical thinking } \\
\text { Ability of discovering } \\
\text { problems, analyzing } \\
\text { problems and solving } \\
\text { problems } \\
\text { Integrated skill } \\
\text { Professional ethics }\end{array}$ & $\begin{array}{lr}\text { Project } & \text { teaching, } \\
\text { comprehensive } & \text { simulation } \\
\text { training, comprehensive } & \\
\text { competition, planning } & \text { pompetition, entrepreneurial } \\
\text { competition, graduation } & \text { grasesional } \\
\text { thesis design, professionat } \\
\text { internship, corporate } \\
\text { temperary appointment }\end{array}$ \\
\hline "body" & High & $\begin{array}{l}\text { Second } \\
\text { semester of } \\
\text { senior year }\end{array}$ & $\begin{array}{l}\text { Off-campus } \\
\text { (industry or } \\
\text { enterprise) }\end{array}$ & $\begin{array}{l}\text { Form a complete knowledge } \\
\text { system and } \begin{array}{r}\text { high } \\
\text { professional technical } \\
\text { ability, and professional } \\
\text { position ability }\end{array}\end{array}$ & $\begin{array}{l}\text { Critical thinking } \\
\text { Teamwork } \\
\text { Communication } \\
\text { Professional ability }\end{array}$ & $\begin{array}{l}\text { Social practice } \\
\text { Graduation internship } \\
\text { Innovation } \\
\text { entrepreneurship }\end{array}$ \\
\hline
\end{tabular}

2) Four integrated marketing practice teaching modes of "class, training, competition and creation": "Class" is to make full use of the practice/experimental platform in the school to carry out experimental teaching, simulation teaching, etc.; or introduce the enterprise lecturer into the classroom, and jointly complete the course with the teachers in the school.

"Training" means to use the off-campus training base efficiently and carry out projects such as study tour, market research, on-site teaching, and simulation teaching. It can not only realize the in-depth utilization of the resources of the cooperative enterprise, but also realize the "real project" and "project real", and train students practically and effectively.

"Competition" is to participate in the industry discipline competition or the "X enterprise cup marketing contest". Through the competition, it can not only enhance the school and professional visibility, and build a brand, but also train students to comprehensive practice.

"Creation" means tutoring students to apply for provincial-level college students' innovation and entrepreneurship training programs, climbing plan projects, challenge cup entrepreneurship projects, and counseling students' entrepreneurial activities. Through the implementation of innovative entrepreneurial projects, it can cultivate students who have excellent academic performance and ability to learn independently will be able to think independently, be active in brains, and be brave in hands-on practice, and train them to have a strong interest in scientific research and social practice and a spirit of hard work.

\section{THE SPECIFIC STRATEGY OF IMPLEMENTING MARKeTING PROFESSIONAL PRACTICE TEACHING BASED ON THE INTEGRATION OF PRODUCTION AND EDUCATION}

The marketing major of the school where the research group is located fully demonstrates the principles of multilevel, systematic and practical in the process of practical teaching. The practical teaching system of "point-line-facebody" modern marketing talent training is effectively implemented based on the professional cognitive practice of the lower grades (in the form of on-site visits or holiday surveys) as the start point, relying on all kinds of course practical teaching links (school-enterprise co-construction courses), taking the participation in corporate project comprehensive practice (holding "X enterprise cup marketing contest", etc.) as the main body, with the graduation thesis and graduation internship (the specific marketing problem of the research enterprise) as the promotion, and taking the student scientific research activity (the specific marketing problem of the research enterprise) as the extension. (See "Fig. 1")

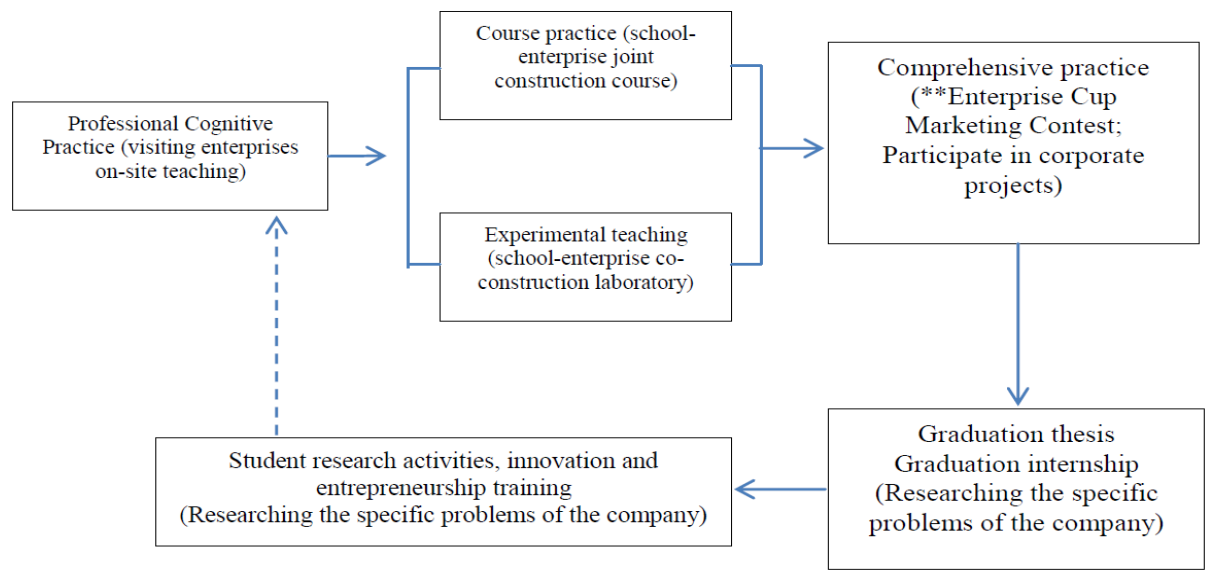

Fig. 1. Production and education integration implementation marketing professional practice teaching chart. 
The specific strategies and practices are as follows:

\section{A. Class - Reforming the Traditional Curriculum and Highlighting the Cultivation of Practical Ability}

On the basis of the traditional curriculum, it will be necessary to highlight the part of improving the practical ability training, and open courses related to innovative practice such as "business planning", "innovative thinking training", "entrepreneurial management" and "entrepreneurial design", and establish independent experimental courses such as "marketing comprehensive simulation training" and "ERP Training". At the same time, according to the content and nature of the course, what needed to do is to implement the school-enterprise coconstruction course, in the "Sales Management", "Marketing Planning", "Advertising" and other courses, and boldly hire corporate executives or sales managers into the classroom, together with the school teachers to complete the course teaching.

\section{B. Training - Improving Project-based Teaching and Training Students' Ability to Solve Problems}

It is necessary to cooperate with enterprises to build internships and training bases. Schools and enterprises should jointly develop practical teaching objectives and talent training programs, establish practical teaching curriculum systems, develop practical courses and training programs, train in-school off-campus practice instructors, and jointly organize practical teaching. For example, it will be important to develop a project plan and cooperate with the enterprise to implement the project. The enterprises conduct the scores and practical application of the program, and propose new problems encountered in the application. The teachers summarize the project execution results and prepares for the next round of new cycles. Through this kind of project-based training, on the one hand, the students' practical ability and ability to solve problems are exercised, and on the other hand, the company has achieved mutually beneficial effects.

\section{Competition - Introducing the "X Enterprise Cup" Marketing Contest and Training Students' Comprehensive Practical Ability}

Great importance should be attached to introduce the "* Industry Cup" and "X Enterprise Cup" business skills competition, such as the "T three organic tea" marketing planning competition and the " $\mathrm{T}$ three organic tea" entrepreneurial competition. Promoting the teaching and promoting the competition by the competition has improved the students' comprehensive practical ability. At the same time, it is beneficial to open up students' vision and enhance students' employment competitiveness. In the process of participating in the competition, it is necessary to carry out market research and creative planning, which not only effectively mobilizes the enthusiasm of students' independent learning, but also enables students to form research interests and cultivate preliminary research ability and cooperation spirit.

\section{Creation - Conducting Research on Corporate Topics and Training Students' Innovative Thinking and Research Capabilities}

The purpose of modern marketing talent training is not only to train qualified production and sales managers, but also to cultivate strategic managers with innovative capabilities and operational methods; to enhance students' ability to innovate while cultivating students' practical ability, and to make a contribution to the promotion of the development of innovative society. Therefore, it is essential of research, exploratory, design, and comprehensive practices to solve practical production and management problems and improve innovation capabilities, as well as social practices aimed at understanding society and national conditions and improving overall quality. Focusing on the actual problems of enterprises, it is a very good attempt to guide students to carry out the project of innovation and entrepreneurship training for college students. For example, the research team guided students to conduct research on the network travel status of Guangzhou travel agencies, Guangzhou regional tourism resources, and Guangzhou Pharmaceutical Group, and apply for and get approved of the Guangdong University Student Innovation and Entrepreneurship Training Program "Guangzhou University Part-time Tour Guide Satisfaction Study", "Ecological Accommodation Experience on Visitors' Environmental Awareness Impact Study", "Guangzhou Pan Gaoshou Weibo Promotion", "New Media Age Development Innovation Path", etc.

\section{INNOVATION IN THE ASSESSMENT AND EVALUATION OF MARKETING PROFESSIONALS}

\section{A. Paying Attention to the Assessment and Evaluation of Practical Teaching}

The purpose of marketing teaching is to emphasize the cultivation of students' innovative spirit and practical ability. The traditional closed-volume assessment method based on knowledge inheritance and memory cannot correctly guide students' learning direction, which is not conducive to the cultivation of students' innovative spirit and practical ability. To this end, it is necessary to comprehensively innovate in many aspects such as the content, methods and performance calculation of the marketing professional course assessment.

The purpose and method of reforming the examination, from the simple test of knowledge and the simple assessment of students' learning ability, to the ability to focus on practice and thinking, the verification and cultivation of innovation consciousness, make the examination become the process of continuing learning. Examinations, assessments, and even graduation thesis of some courses may be considered by submitting a corporate case investigation report or submitting a creative planning book. The level of grade can be determined by the innovation and operability of the program. In the selection of assessment content, both the knowledge and the ability need to be tested, focusing on assessing the students' comprehensive quality and practical innovation ability. In the assessment method, according to the characteristics of the marketing course, a variety of 
examination and assessment methods can be adopted such as closed-book written test, open-book written test, oral test, simulation operation, case analysis report, and planning design. In judging the achievements of students, it will be necessary to reform the traditional academic evaluation system based on the final exam results, and increase the number of scoring methods such as written answers, classroom demonstrations, and operational skills assessment. In this way, it can promote the comprehensive development of students' individuality and ability by reforming examination and assessment methods. The research team proposed an innovative evaluation system for marketing professionals, as shown in "Table II".

TABLE II. Design of Marketing Professional AsSESSMENT System

\begin{tabular}{|c|c|c|c|c|}
\hline & Assessment link & Weights (\%) & Examination content & Proportion (\%) \\
\hline \multirow{6}{*}{$\begin{array}{l}\text { Marketing professional } \\
\text { assessment }\end{array}$} & \multirow{4}{*}{ Ordinary assessment } & \multirow{4}{*}{$40-50$} & Class discussion and presentation & 30 \\
\hline & & & $\begin{array}{l}\text { Finish homework or exercises after } \\
\text { class }\end{array}$ & 30 \\
\hline & & & Answer the question and test on paper & 20 \\
\hline & & & Innovation activity & 20 \\
\hline & \multirow{2}{*}{ Final-examination } & \multirow{2}{*}{$60-50$} & $\begin{array}{l}\text { Basic theory and knowledge } \\
\text { assessment }\end{array}$ & 50 \\
\hline & & & $\begin{array}{l}\text { Comprehensive application ability } \\
\text { assessment }\end{array}$ & 50 \\
\hline
\end{tabular}

\section{B. Paying Attention to the Process Evaluation}

The new assessment and evaluation system requires the combination of the usual assessment and the final examination, the combination of quantitative indicators and non-quantitative indicators, the combination of oral expression and written expression, professional assessment and quality assessment, and comprehensive assessment of student achievement using a variety of assessment methods, which can avoid the shortcomings of the final examination. At the same time, the assessment will run through the whole process of teaching. Continuous assessment will be carried out in the teaching process, in the daily teaching. The usual assessment methods are: after-school homework, discussion speeches, tests and exams. After-school assignments include writing course papers, business planning reports, market research reports, special research reports, etc. Discussions and presentations include group work presentations, group or placement discussions, class topic discussions, and business plan presentations. And quizzes and exams include answers on paper, unit tests, etc.

The scoring standards for daily assignments, course papers, class discussions and presentations are also quantified as much as possible, and efforts are made to improve the accuracy of the assessment results. The assessment content includes basic theory and basic knowledge, as well as students' comprehensive ability and speculative ability. It also pays attention to students' learning attitude, input status and learning initiative, innovation, highlighting comprehensive characteristics, and combining diversified evaluation methods and the assessment of standardized evaluation indicators. Generally speaking, through the written test and the oral test, the students' mastery of the basic theories and basic knowledge of the teaching are mainly assessed; the students' comprehensive ability and speculative ability are mainly assessed through discussion and homework; through on-the-spot questions, speeches, attendance and the results of after-school innovation activities, the students' attitudes, style of study and initiative and innovation are mainly assessed.

\section{Focusing on Student-centered Evaluation}

The reform of practical teaching links includes reforms in both teaching methods and learning methods. In the past practice teaching, it should mainly focus on case teaching, emphasizing the reform of teaching methods, and neglecting the reform of learning methods. The teaching method of science should teach students to practice, accumulate innovative experience, and improve their hands-on ability, not just to understand the case. Only when the combination of teaching methods and learning methods can be reformed can the practical teaching truly shift from a teacher-centered to a student-centered, from the mastery of students' knowledge to the cultivation of students' ability, and truly play the role of student-oriented to have a sense of sustainability and ability.

\section{Focusing on Introducing Companies or Third-party Evaluations}

It will be important to promote the precise integration of marketing professionals with industries and enterprises, and gradually incorporate them into relevant industries, enterprises or third-party evaluation agencies in teaching and management. The use of third-party professional evaluation agencies to "change one eye to see a professional, change one eye to see a teacher, and change one eye to see a student" can not only ensure the professionalism of the professional school or the teacher's business, the professionalism of the problem, but also demonstrate the practicality and objectivity of the problem, and is more grounded. From "mastery of pure knowledge of inspection" to "the ability to pay attention to practice and thinking, the 
verification and cultivation of innovation consciousness", the assessment and evaluation has become the process of continuing learning, and has become a baton that effectively promotes the improvement of students' academic science.

\section{CONCLUSION}

The application and comprehensive characteristics of the marketing profession require the marketing profession to focus on the theory and practice, and focus on the comprehensive application of theories and methods. The aim is to train students to use their knowledge, theory, etc., to provide problem solutions for marketing strategy management, market development, marketing planning, brand promotion and operation management of enterprises and institutions, and to cultivate students with innovative and complex qualities to meet the needs of national economic construction and the needs of industrial development. Therefore, closely focusing on industrial needs and market changes, carrying out the integration of production and education, collaborative education, strengthening practical teaching, and perfecting the training system based on applied talents are the proper meanings for the training of professional marketing talents. On the basis of adhering to the cognitive rules of teaching and the characteristics of business education, marketing majors should vigorously carry out the integration of production and education, schoolenterprise cooperation, and establish a three-dimensional, multi-level, open-ended practical teaching system. It also focuses on taking students as the center, implementing process assessment, focusing on introducing enterprises, society or third-party evaluations, and promoting the improvement of education and teaching quality monitoring.

\section{REFERENCES}

[1] GuoBan Fa, Several Opinions of the General Office of the State Council on Deepening the Integration of Production and Education [R]. General Office of the State Council, 2017, 12. (in Chinese)

[2] Wu Xinling, Wen Youyun, Constraints and Improvement Measures of Practical Teaching Effect in Business Majors: Based on Questionnaire Survey [J]. Education Modernization, 2018, 5 (43): $119-121+126$. (in Chinese)

[3] Wang Weihong, A Design of the Business Management Discipline Practice Teaching System [J]. Journal of Jiaying University, 2007 (02): 65 - 67. (in Chinese)

[4] Li Zhiguo, Yuan Li, On the Innovation of Practice Teaching Mode of Moot Court from Point to Line and then Plane and Overall - Based on the Practice of Academic Competitions [J]. Journal of Heilongiiang Administrative Cadre College of Politics and Law, 2014 (01): 142 - 144. (in Chinese)

[5] Wu Xinling, Chen Shuxing, Research Status and Prospects of Practical Teaching Evaluation System for Business Majors in Independent Colleges [J]. Journal of Chifeng College: Natural Science Edition, 2016, 32 (04): 248 - 250. (in Chinese)

[6] Wang Weihong, An Exploration of the Teaching Models and Practical Teaching Strategies Oriented towards Innovative Ability Cultivation: Taking the Marketing Major as an Example [J]. Journal of Guangdong University of Foreign Studies, 2009, 20 (03): 100 103. (in Chinese) 